\title{
APPLICATION OF A TAG PARASITE, ANISAKIS SP., INDICATES A COMMON FEEDING MIGRATION FOR SOME GENETICALLY DISTINCT NEIGHBOURING POPULATIONS OF HERRING, CLUPEA HARENGUS
}

\author{
Mikael van $D E U R S^{*}$ and Kasper RAMKAER
}

Danish Institute of Fisheries Research (DIFRES), Department of Marine Fisheries, Charlottenlund, Denmark

van Deurs M., Ramkær K. 2007. Application of a tag parasite, Anisakis sp., indicates a common feeding migration for some genetically distinct neighbouring populations of herring, Clupea harengus. Acta Ichthyol. Piscat. 37 (2): 73-79.

Background. Recent research showed a particularly pronounced genetic diversity for the Atlantic herring, Clupea harengus, living in the transition zone from the Baltic Sea to the North Sea. Conserving genetic diversity is of high priority in fishery management. This requires, firstly, that we recognize life histories, not only of the major spawning components, but also of the smaller ones, and secondly, that we improve our knowledge on how genetic diversity is maintained also on smaller geographical scale.

Materials and Methods. Prevalence of the widely used tag parasite Anisakis sp. was applied to investigate whether the various spawning components, living in the Baltic Sea-North Sea transition zone, display any common features with respect to feeding migration patterns.

Results. It is strongly suggested that spawning components in the transition zone migrate to feeding areas in Skagerrak or the North Sea. This implies that herring utilizing spawning grounds in the Limfjord and inner Danish waters engage in a northward feeding migration like their nearby neighbour, the Rügen Herring, instead of feeding locally or in the Baltic Sea.

Conclusions. Firstly, these results support the validity of the present division of management areas, where the Western Baltic Sea is managed under ICES Division IIIa (Kattegat and Skagerrak), even when the newly discovered population complexity is considered. Secondly, it contributes to the debate on how population complexes can be sustained despite temporary mixing, where it support the idea that genetic divergence in herring population complexes can arise from colonization of unused spawning grounds and be sustained despite extensive temporal mixing by natal homing.

Keywords: Anisakis, biological tag, parasite, fish, herring, Clupea harengus, migration, Western Baltic Sea

\section{INTRODUCTION}

Recent published work discovered a high degree of genetic diversity in the Atlantic herring, Clupea harengus. In the transition zone from the Baltic Sea to the North Sea a particular large number of multiple, genetically distinct, sympatric spring spawning population components were found (Bekkevold et al. 2005, Mariani et al. 2005, Ruzzante et al. 2006). Maintaining genetic diversity is of high priority in fishery management, and before such diversity can be ensured we need to recognize life histories not only of the major spawning components but also of the smaller components.

The Rügen Herring, which spawns around the Rügen Island on the German coast have due to its commercial importance received attention in the literature. However, documentation of aspects of the life histories of the neigh- bouring spawning components of the inner Danish waters was completely lacking until 2005, when Bekkevold et al. (2005) and Ruzzante et al. (2006) were able to link a fraction of the feeding aggregations in Skagerrak to genetically distinct population components from the inner Danish waters and the Western Baltic Sea. The micro-satellite methods used were, however, not adequate to distinguish between the various Western Baltic components when applied to samples from the mixed Skagerrak aggregations. Furthermore, linking herring from the mixed feeding aggregations back to their respective spawning grounds is not indisputable proof that the entire spawning component participates in the respective feeding aggregation. To do this, a method, which is capable of tracking ripening herring, sampled on spawning grounds, back to their feeding grounds is required. Therefore, the use of a tag-parasite is proposed. Since 1939,

\footnotetext{
* Correspondence: Mr. Mikael van Deurs, Danmarks Fiskeriundersøgelser, Afdelingen for Havfiskeri, Charlottenlund Slot, Jægersborg Allé, DK-2920 Charlottenlund, Denmark, phone: +45 20499954, fax: +45 33963333, e-mail: mvd@difres.dk
} 
parasites have been employed as biological tags (see: MacKenzie and Abaunza 1998, MacKenzie 2002). Parasites employed as biological tags belong to various taxonomic groups, such as helminth parasites (Berland 1984) and crustacean parasites (Kabata 1970). Among the nematodes, in particular the genus Anisakis (cf. Chenoweth et al. 1986, Abaunza et al. 1995) and Hysterothylacium (cf. GeorgeNascimento and Arancibia 1992) have been applied with success. Anisakis sp. played a major role in recognizing migratory differences in the Western Baltic Sea, when researchers established that the adult Rügen Herring after spawning engage in a northward feeding migration to feeding areas in Skagerrak and the North Sea, and significantly improved our knowledge of the herring population structures in the Baltic Sea (Grabda 1974, Biester 1979, Biester et al. 1979, Jönsson and Biester 1979, Podolska and Horbowy 2003).

A successful tag parasite for the type of study presented here should be long-lived in its fish host and infection levels should vary within the study area (Lester 1990, MacKenzie and Abaunza 1998). Anisakis sp. has been observed to survive for at least several years and possibly the entire life of the herring and causes minor or no harm at all to its host (Smith 1984). It will therefore accumulate over time (e.g., Bishop and Margolis 1955, Davey 1972, Grabda 1974, Horbowy and Podolska 2001, Podolska and Horbowy 2003). Klimpel et al. (2004) reviewed the general accepted aspects of the lifecycle of Anisakis sp. Anisakis sp. produces its eggs while inside various marine mammals and the eggs enter the water-column with the host's faeces. The egg or a free-swimming third stage larva (L3) is then consumed by the first intermediate host, a crustacean. Traditionally krill (Euphausiacea) have been considered the most important carrier of Anisakis sp. into herring (Sluiters 1974). As a consequence herring are not likely to become infected outside the geographical distribution of the krill, such as the Baltic Sea (Grabda 1974).

The aim of this study was to apply the well known tag parasite Anisakis sp. to test the hypothesis that the newly discovered spring spawning components of the inner Danish waters feed locally or in the Baltic Sea.

\section{MATERIALS AND METHODS}

Study area. The study area is characterized by a strong vertical- and horizontal salinity gradient with dense saline Atlantic water, flowing in from the north, and less dense brackish water flowing out of the Baltic. A deep trench, the Norwegian Deep, runs along the Norwegian- and Swedish Skagerrak coasts, extending into the Northern Kattegat. The remaining parts of Skagerrak and Kattegat are relatively shallow $(0-50 \mathrm{~m})$ (Fig. 1). Krill are assumed to aggregate in the deep, higher-salinity parts of Skagerrak and sporadically in the deep parts of northern Kattegat, whereas the southern Kattegat, inner Danish waters, and the Baltic Sea are outside its geographical distribution (e.g., Ulmestrand and Hagström 1992, Tarling et al. 1998).

Sampling. The present study is based on herring sampled in 2002 and 2003, from 33 different sample locations, within the area connecting the Baltic Sea to the North Sea
(Western Baltic Sea, Kattegat, and Skagerrak) (Fig. 1). Samples were provided by the HERGEN EU-project (www.hull.ac.uk/hergen) and correspond to the samples, which provided tissue for the genetic analysis in Bekkevold et al. (2005) and Ruzzante et al. (2006). Feeding areas were sampled offshore in Skagerrak and Kattegat (offshore samples) during weeks 26 and 27 on the Danish research vessel $\mathrm{R} / \mathrm{V} D A N A$. Fishing was carried out with a 16-mm Fotö trawl. From each catch one sample of up to one hundred herring, and a maximum of ten from each length group, were placed in a tunnel freezer and rapidly cooled to $-23^{\circ} \mathrm{C}$ approximately $1 \mathrm{~h}$ after they were landed. Coastal spawning grounds were sampled (spawning samples) from commercial trap-net catches during the spring spawning events. Offshore samples contain a mixture of herring from the various population components (Bekkevold et al. 2005, Ruzzante et al. 2006). The samples were treated, according to routine protocols, by the laboratory staff of IMR and DIFRES: Total fish length (TL) was measured and rounded down to the nearest $\mathrm{cm}$. Visual examination of the gonads was carried out to ensure that the herring were either approaching sexual maturity, mature, or spent (maturity index 5 to 8 according to Johansen (1919)). The otoliths were retrieved and aged according to the number of winter rings. Spawning type (autumn, spring, or winter) was determined according to Mosegaard and Madsen (1996) and Clausen et al. (2007). Herring from spawning samples with a maturity index below 5 together with autumn spawners from offshore samples were excluded from the further analysis.

Infection: comparing spawning grounds to offshore Skagerrak. Infection was measured as prevalence (e.g., Bush et al. 1997, Podolska and Horbowy 2003) in 1992 herring from 27 of the 33 sample location (Table 1). A herring was registered as infected if one or more nematodes were visually detectable by the naked eye, just after an incision along the entire length of the abdomen had been made and the internal organs within the abdominal cavity exposed. Prevalence was calculated by dividing the number of infected herring with the total number of sampled herring within length or age groups, resulting in the frequency of infected herring. Five nematodes were randomly retrieved from each sample locations for the genus identification and stored in alcohol. The alcohol-preserved worms were subsequently soaked in tap water for $1 \mathrm{~h}$ followed by a 1-h bath in 25-\% lactic acid. Schematic drawings, published by Buchmann (1998), were applied as guidelines to determine the genus under a dissection microscope. Only nematodes of the genus Anisakis were found.

Infection: comparing offshore Skagerrak to offshore Kattegat. Nematodes were counted in herring from twelve (only samples of 2003) out of the 33 sample locations, four from offshore Kattegat and eight from offshore Skagerrak. Internal organs were moved to a Petri dish and submerged in alcohol. After a few minutes the tissues of the nematode were coagulated and the worms were easily identified under a dissection microscope. Lastly, the walls of the empty abdominal cavity were searched for nematodes. Nematodes, which might have been inside muscles and organs, were not included in the analysis. 


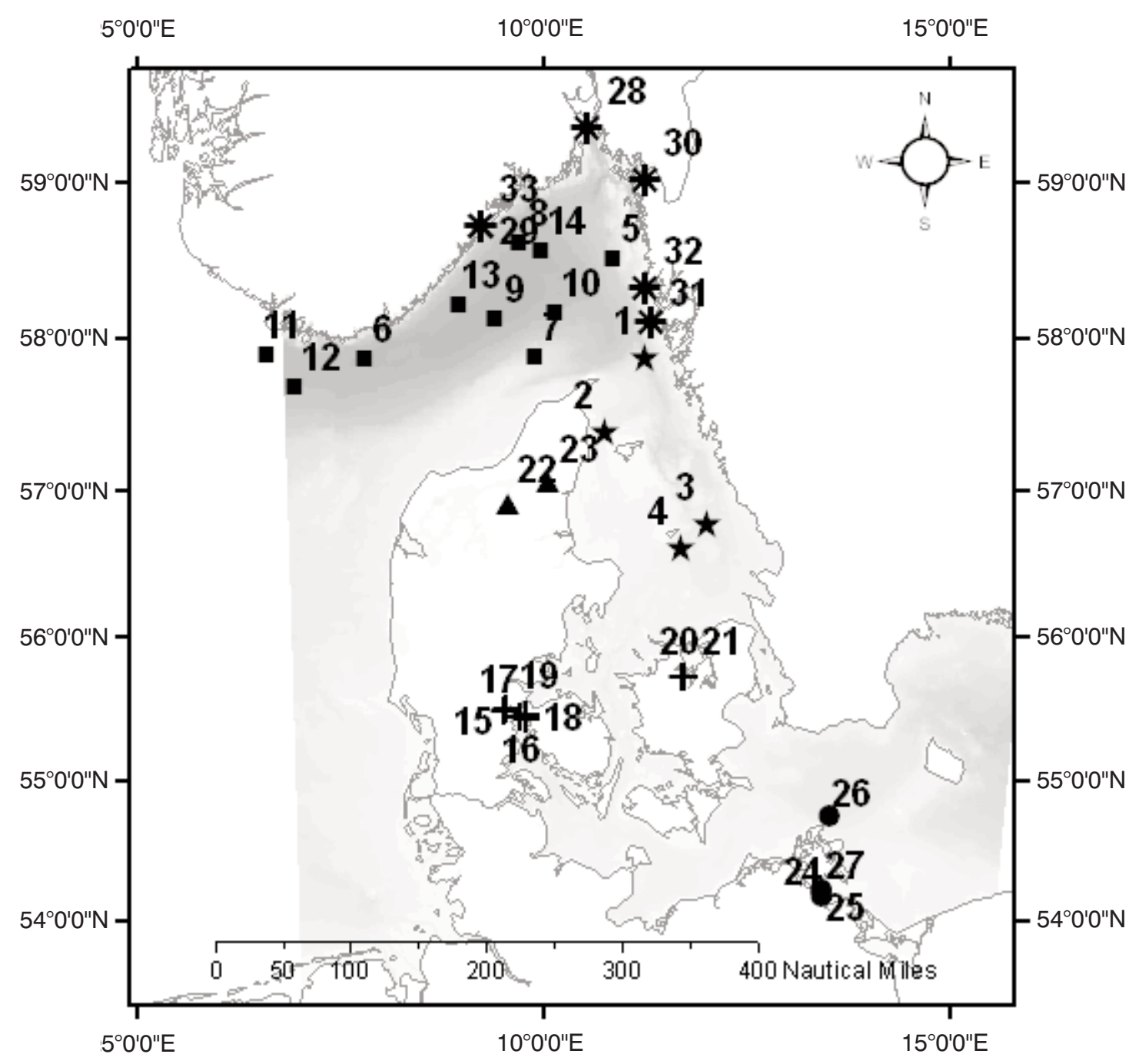

Fig. 1. Map of the study area; a sample location ID number is provided for each sample location; sample locations belong to one of six areas: Rügen (filled circles), inner Danish waters (plusses), Limfjord (triangles), Skagerrak spawning grounds (*), offshore Kattegat (stars), and offshore Skagerrak (squares); a grey scale illustrates the depth contours with the darkest grey representing the deepest areas

A logistic regression model of prevalence. The independent effects of TL, age, year, and area, respectively, on prevalence were tested using logistic regression analysis. The glm procedure in R (Anonymous 2007) was applied to carry out the analysis by choosing a binomial distribution and a logit link function (Hastie and Pregibon 1992). The parameter estimated for a variable were considered to be significantly different from 0 when $P<0.05$.

\section{RESULTS}

The logistic regression model of prevalence. A logistic regression model was fitted to the subset of the prevalence data, which included herring measuring $24 \mathrm{~cm}$ and longer, since no herring smaller than $24 \mathrm{~cm}$ was found on the spawning grounds.

The residual deviance of the model was 870 with 1150 degrees of freedom and approximative distributed according to the chi-square distribution. Therefore as the $95 \%$ quantile of the chi-square distribution with 1150 degrees of freedom is 1230 the model is accepted (Parameter estimates and statistics are provided in Table 2).

Effect of length and age on infection. First all data was pooled to assess how prevalence was affected by age and length. Prevalence increased with length and age. The slope of increase with length was initially steep but flattened off around $26-28 \mathrm{~cm}$ and prevalence of $75 \%$ to $90 \%$, depending on age. Older individuals, in general, had a slightly higher prevalence compared to younger individuals within the same length group (Fig. 2), though this was not significant when tested in the logistic regression (Table 2).

Infection: comparing spawning grounds to offshore Skagerrak. Prevalence was calculated for five groups: Rügen (spawning ground), inner Danish waters (spawning ground), the Limfjord (spawning ground), coastal Skagerrak (spawning ground), and offshore Skagerrak (feeding area). All groups came out with prevalence levels above 0.80 for herring larger than $26 \mathrm{~cm}$ (Table 1, Fig. 3). No group stood significantly out from the rest (Table 2). 
Prevalence, sample sizes (n), and sample ID (see Fig. 1) for five respective groups

\begin{tabular}{|c|c|c|c|c|c|}
\hline Area & $\begin{array}{l}\text { Type of fish } \\
\text { concentration }\end{array}$ & $\begin{array}{c}\text { Length group } \\
{[\mathrm{cm}]}\end{array}$ & $\begin{array}{c}\text { Prevalence } \\
{[\%]}\end{array}$ & $\mathrm{n}$ & $\begin{array}{l}\text { Samples } \\
\text { [ID/year] }\end{array}$ \\
\hline \multirow{6}{*}{ Skagerrak } & \multirow{6}{*}{ feeding } & $18-20$ & 0 & 8 & \multirow{6}{*}{$\begin{array}{c}5 / 03,6 / 03,7 / 03,8 / 02 \\
9 / 02,10 / 02,11 / 02 \\
12 / 03,13 / 03,14 / 03\end{array}$} \\
\hline & & $20-22$ & 19 & 79 & \\
\hline & & $22-24$ & 37 & 111 & \\
\hline & & $24-26$ & 84 & 61 & \\
\hline & & $26-28$ & 86 & 7 & \\
\hline & & $28-30$ & $*$ & 2 & \\
\hline \multirow{6}{*}{ Inner Danish waters } & \multirow{6}{*}{ spawning } & $20-22$ & $*$ & 2 & \multirow{6}{*}{$\begin{array}{c}15 / 02,16 / 02,17 / 02, \\
18 / 03,19 / 03,20 / 02 \\
21 / 03\end{array}$} \\
\hline & & $22-24$ & $*$ & 5 & \\
\hline & & $24-26$ & 61 & 115 & \\
\hline & & $26-28$ & 88 & 209 & \\
\hline & & $28-30$ & 96 & 137 & \\
\hline & & $30-32$ & $*$ & 1 & \\
\hline \multirow{5}{*}{ Limfjord } & \multirow{5}{*}{ spawning } & $24-26$ & 86 & 7 & \multirow{5}{*}{$22 / 02,23 / 03$} \\
\hline & & $26-28$ & 100 & 24 & \\
\hline & & $28-30$ & 97 & 33 & \\
\hline & & $30-32$ & 100 & 7 & \\
\hline & & $32-34$ & $*$ & 1 & \\
\hline \multirow{5}{*}{ Rügen } & \multirow{5}{*}{ spawning } & $22-24$ & $*$ & 1 & \multirow{5}{*}{$24 / 02,25 / 02,26 / 02,27 / 03$} \\
\hline & & $24-26$ & $*$ & 4 & \\
\hline & & $26-28$ & 82 & 56 & \\
\hline & & $28-30$ & 94 & 119 & \\
\hline & & $30-32$ & 100 & 21 & \\
\hline \multirow{6}{*}{ Skagerrak } & \multirow{6}{*}{ spawning } & $24-26$ & 79 & 61 & \multirow{6}{*}{$\begin{array}{l}28 / 02,29 / 02,30 / 02 \\
31 / 02,32 / 02,33 / 03\end{array}$} \\
\hline & & $26-28$ & 83 & 183 & \\
\hline & & $28-30$ & 86 & 234 & \\
\hline & & $30-32$ & 96 & 48 & \\
\hline & & $32-34$ & 93 & 15 & \\
\hline & & $34-36$ & $*$ & 1 & \\
\hline
\end{tabular}

* Prevalence was not calculated due to small sample size $(n<7)$.

Table 2

Parameter estimates and statistics of the logistic regression model

\begin{tabular}{lccc}
\hline Variable & Parameter estimate & Standard error & $P$ \\
\hline (Intercept) & -7.761 & 1.484 & $<0.001^{* * * *}$ \\
Factor (year) 2003 & 0.275 & 0.233 & 0.237 \\
Covariate (age) & 0.074 & 0.142 & 0.604 \\
Covariate (TL) & 0.367 & 0.063 & $<0.001^{* * *}$ \\
Factor (area) inner Danish waters & -0.611 & 0.420 & 0.146 \\
Factor (area) Limfjord & 1.123 & 0.822 & 0.172 \\
Factor (area) Rügen & -0.348 & 0.480 & 0.467 \\
Factor (area) spawning ground in Skagerrak & -0.638 & 0.427 & 0.135 \\
\hline
\end{tabular}

$* P<0.05 ; * * P<0.01 ; * * * P<0.001$.

Infection: comparing offshore Skagerrak to offshore alone was infected with up to eight nematodes per individKattegat. Herring from Kattegat were mainly age group 1 ual in Skagerrak, and as much as 33\% of age group 2 was and age group 2 and they were almost Anisakis-free with infected with up to 17 nematodes per individual (Table 3). only $3 \%$ being infected, and no more than one nematode In order to statistically treat the difference, the nematode was found per individual. In contrast $13 \%$ of age group 1 counts, provided in Table 3 , were subsequently converted 
Table 3

Comparing nematode counts in samples from offshore Kattegat (ID 1-4, see Fig. 1) and offshore Skagerrak (ID 5-10 and 12-13, see Fig. 1); the fraction of herring with 1, 2, 3,...or 17 Anisakis nematodes, respectively, within specified age and length groups is presented

\begin{tabular}{|c|c|c|c|c|c|c|c|c|c|c|c|}
\hline \multirow[t]{2}{*}{ Area } & \multirow{2}{*}{$\begin{array}{c}\text { Age } \\
\text { [years] }\end{array}$} & \multirow{2}{*}{$\begin{array}{c}\text { Length } \\
\text { group } \\
{[\mathrm{cm}]}\end{array}$} & \multirow[t]{2}{*}{$n$} & \multicolumn{8}{|c|}{$\begin{array}{l}\text { Percentage of herring sampled with respectively } 0,1,2 \ldots \text { or } 7+\text { nematodes } \\
\text { in the abdominal cavity }\end{array}$} \\
\hline & & & & 0 & 1 & 2 & 3 & 4 & 5 & 6 & $7+$ \\
\hline \multirow{2}{*}{ Kattegat } & 1 & $16-20$ & 83 & 96.4 & 3.6 & 0 & 0 & 0 & 0 & 0 & 0 \\
\hline & 2 & $20-22$ & 19 & 100 & 0 & 0 & 0 & 0 & 0 & 0 & 0 \\
\hline \multirow{2}{*}{ Skagerrak } & 1 & $16-20$ & 292 & 88.4 & 11.0 & 0.3 & 0.3 & 0 & 0 & 0 & 0 \\
\hline & 2 & $20-22$ & 249 & 67.9 & 17.3 & 4.4 & 5.2 & 1.6 & 0.8 & 0.4 & 2.4 \\
\hline
\end{tabular}

into a measure of prevalence and the logistic regression approach applied for the prevalence data was adopted. The difference between offshore Kattegat and offshore Skagerrak was significant (Parameter estimate for offshore Skagerrak: 2.70; Standard error: $0.62 ; P=0.00001 ; 640$ degrees of freedom; residual deviance: 549 ).

\section{DISCUSSION}

Results of the present study showed that herring from spawning grounds in the inner Danish waters and the Limfjord showed values of prevalence which resembled (1) spawning samples taken in the fjords on the Norwegian and Swedish Skagerrak coast, (2) the Rügen spawning component (that is known to engage in a northern feeding migration to Skagerrak or the North Sea), and (3) offshore Skagerrak during the feeding season, while herring from off-shore Kattegat were significantly less infected. Furthermore, prevalence in general increased with size as has previously been reported (Grabda 1974, Chenoweth et al. 1986), and which according to Lester (1990) is in support of the suitability of the parasite as a biological tag for the type of study presented here. However, it is worth noting that in the present study the rate of increase in prevalence with size declined considerably for herring larger than $26 \mathrm{~cm}$. It may even be argued that the prevalence reaches a plateau below 100\%. Davey (1972)

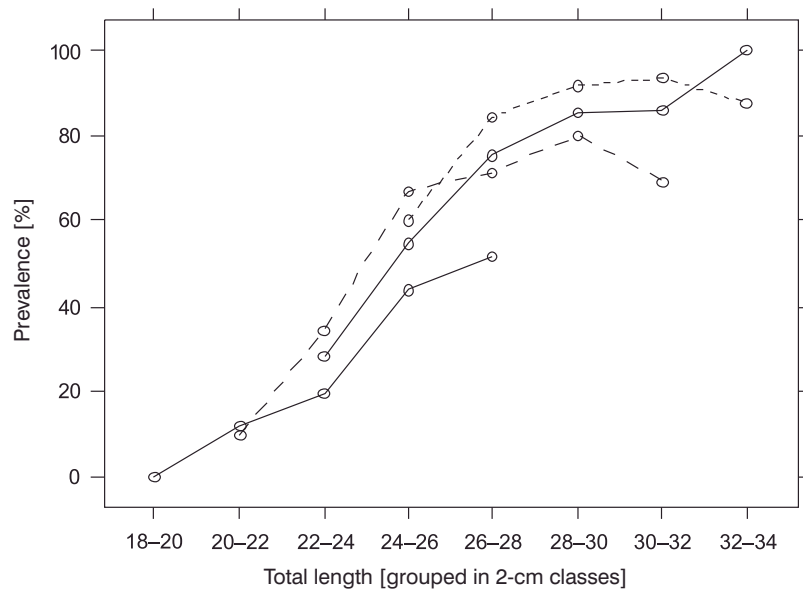

Fig. 2. Line plot showing the relation between prevalence (y-axis) and two-centimetre length groups (x-axis) for age 2 (bold solid line), 3 (bold broken line), 4 (thin solid line) and 5 (thin broken line), respectively

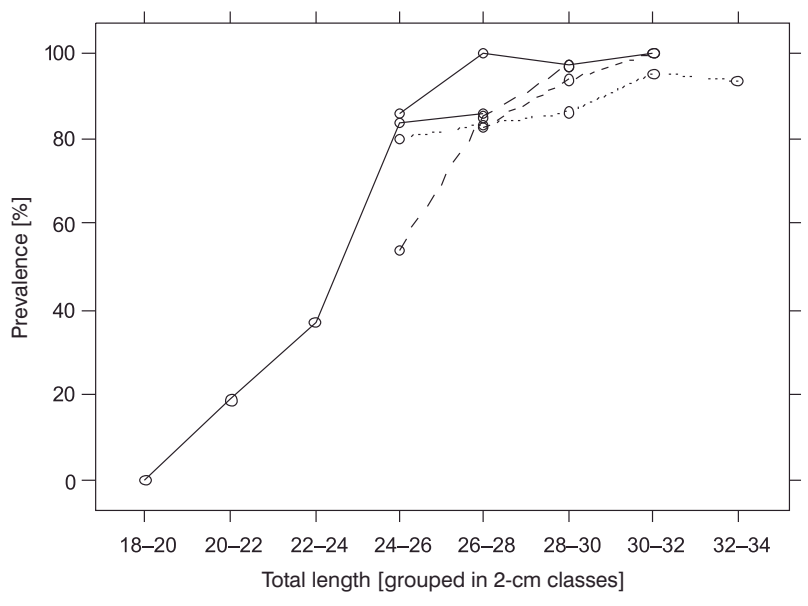

Fig. 3. Line plot showing the relation between prevalence (y-axis) and two-centimetre length groups (x-axis) for Rügen (thin dashed line), inner Danish waters (bold dashed line), spawning grounds in Skagerrak (dotted line), the Limfjord (thin solid line) and the feeding area of offshore Skagerrak (bold solid line) respectively

also reported that prevalence reaches a plateau in herring (C. harengus) from British waters.

No publications on Anisakis sp. of herring from Skagerrak are available. The literature covering the North Sea reports prevalence levels, for herring feeding in the North Sea outside the 50-m isobath (Khalil 1969) and for spawning aggregations on the North Sea Dogger Bank (van Banning and Becker 1976), in the same order of magnitude as was here found on spawning grounds including the inner Danish Waters and the Limfjord. In contrast to these relatively high levels of infection, far lower values have been reported from the shallow southeastern part of the North Sea inside the 50-m isobath (Khalil 1969). There is a consensus, that in general, in the Baltic Sea the infection rates are extremely low. This is explained by the Baltic Sea being outside the geographical distribution of krill, due to its relatively low depths and brackish waters. Kattegat (the transition zone between the Baltic Sea and Skagerrak) represents an extremity in the distribution range of krill (Tarling et al. 1998), which corresponds to the near absence of Anisakis in herring from Kattegat, found in the presently reported study. It should be noted, however, that several 
studies describe a population of krill (Meganyctiphanes norvegica) living in a physical niche within the otherwise sub optimal environments in the northern Kattegat, mainly east of Læsø (Boysen and Buchholtz 1984, Ulmestrand and Hagström 1992, Tarling et al. 1998). Even though Anisakis sp. has been reported in other planktonic crustacean phyla, krill are assumed to be the major source of Anisakis sp. in herring (e.g., Grabda 1974, Sluiters 1974, Smith and Wootten 1978, Last 1989, Podolska and Horbowy 2003). An exception from this general statement were results of Klimpel et al. (2004), suggesting that, in the Norwegian Deep, hyperiid amphipods were more important intermediate host for Anisakis sp. If other crustacean taxa, however, should play a role as intermediate host, as suggested by Klimpel et al. (2004), it is possible that they too may be restricted to the deep- and higher-salinity water-column of Skagerrak and the northern North Sea.

The above discussion leads to the rejection of the hypothesis put forward in the introduction, which stated that spring spawning spawning components, utilizing spawning grounds of the inner Danish waters feed locally or in the Baltic Sea. Therefore we conclude that they must engage in a northward feeding migration, like their closest neighbour, the Rügen herring. This is particularly interesting in the light of findings by Bekkevold et al. (2005), who reported inter-specific genetic divergence amongst the spawning ground divisions applied in the present study. Later, Bekkevold et al. (2007) found that the spawning components from Rügen, inner Danish waters, and Limfjord, respectively, have a common origin.

The present results have implications for biological science in general as well as for fishery management in particular. Firstly, they suggest that herring population components in the Western Baltic Sea in general share some common features with respect to migration patterns as opposed to the herring populations in the remaining part of the Baltic Sea. Secondly, they contribute to the debate on how population complexes can be sustained despite temporary mixing and support the idea that genetic divergence in herring population complexes can arise from colonization of unused spawning grounds and upheld despite extensive temporal mixing by natal homing. A corresponding study, from the coasts of Maine, USA, also employing Anisakis sp. as a tag parasite, supports the suggestion that population structures can be upheld despite mixing during feeding (Chenoweth et al. 1986). Lastly, the presently reported results support that the present division of management areas, where the Western Baltic Sea is managed under ICES Division IIIa (Kattegat and Skagerrak), is valid also when the population complexity discovered by Bekkevold et al. (2005), Mariani et al. (2005), and Ruzzante et al. (2006) is considered.

\section{ACKNOWLEDGEMENTS}

We acknowledge that the herring samples were kindly provided in the frames of the EU-project HERGEN (www.hull.ac.uk/hergen). We would like to thank the laboratory assistants at Institute of Marine Research (IMR) and Danish Institute of Fisheries Research (DIFRES) who helped collecting, measuring, aging, and recording Anisakis in the herring. Furthermore, we sincerely appreciate the opportunities to discuss relevant scientific methodologies, problems and topics with Professor Henrik Gislason (University of Copenhagen), Dr Henrik Mosegaard (DIFRES), cand. scient. biol. Lotte Worsøe Clausen (DIFRES), and Professor Kurt Buchmann (The University of Copenhagen). Last but not least we would like to thank Dr Karin Hüssy (DIFRES) for advice on scientific writing.

\section{REFERENCES}

Abaunza P., Villamor B., Pérez J.R. 1995. Infestation by larvae of Anisakis simplex (Nematoda, Ascaridata) in horse mackerel, Trachurus trachurus, and Atlantic mackerel, Scomber scombrus, in ICES Divisions VIIIb, VIIIc and IXa (N-NW of Spain). Scientia Marina 59: 223-233.

Anonymous 2007. The $\mathrm{R}$ project for statistical computing. http://www.r-project.org

Bekkevold D., André C., Dahlgren T.G., Clausen L.A.W., Torstensen E., Mosegaard H., Carvalho G.R., Christensen T.B., Norlinder E., Ruzzante D.E. 2005. Environmental correlates of population differentiation in Atlantic herring. Evolution 59: 2656-2668.

Bekkevold D., Clausen L.A.W., Mariani S., André C., Christensen T.B., Mosegaard H. 2007. Divergent origins of sympatric herring population components determined using genetic mixture analysis. Marine Ecology Progress Series 337: 187-196.

Berland B. 1984. Basic techniques involved in helminth preservation. Systematic Parasitology 6: 242-245.

Biester E. 1979. The distribution of the Rügen spring herring. ICES Document CM/J: 31.

Biester E., Jönsson N., Hering P., Thieme Th., Brielmann N., Lill D. 1979. Studies on Rügen herring. ICES Document CM/J: 32 .

Bishop Y.M.M., Margolis L. 1955. A statistical examination of Anisakis larvae (Nematoda) in herring (Clupea pallasi) of the British Columbia coast. Journal of the Fisheries Research Board of Canada 12: 571-592.

Boysen E., Buchholz F. 1984. Meganyctiphanes norvegica in the Kattegat - Studies on the annual development of a pelagic population. Marine Biology 79: 195-207.

Buchmann K. 1998. Anisakiasis—En zoonose forårsaget af nematoder i fisk. [Anisakiasis - a zoonosis caused by nematodes in fish.] Dansk Veterinærtidskrift 81 (13): 489-492. [In Danish.]

Bush A.O., Lafferty K.D., Lotz J.M., Shostak A.W. 1997. Parasitology meets ecology on its own terms: Margolis et al. revisited. Journal of Parasitology 83: 575-583.

Chenoweth J.F., McGladdery S.E., Sindermann C.J., Sawyer T.K., Bier J.W. 1986. An investigation into the usefulness of parasites as tags for herring (Clupea harengus) stocks in the western North Atlantic, with emphasis on use of the larval nematode Anisakis simplex. Journal of Northwest Atlantic Fishery Science 7: 25-34.

Clausen L.A.W., Bekkevold D., Hatfield E.M.C., Mosegaard H. 2007. Application and validation of otolith microstructure as a stock identification method in mixed Atlantic herring (Clupea harengus L) stocks in the North Sea and western Baltic. ICES Journal of Marine Science 64: 377-385. 
Davey J.T. 1972. Incidence of Anisakis sp. larvae (Nematoda: Ascaridata) in commercially exploited stocks of herring (Clupea harengus L., 1758) (Pisces: Clupeidae) in British and Adjacent Waters. Journal of Fish Biology 4: 535-554.

George-Nascimento M., Arancibia H. 1992. Stocks ecológicos del jurel (Trachurus symmetricus murphyi Nichols) en tres zonas de pesca frente a Chile, detectados mediante comparación de su fauna parasitaria y morfometriá. Revista Chilena de Historia Natural 65: 453-470.

Grabda J. 1974. The dynamics of the nematode larvae, Anisakis simplex (Rud.) invasion in the south-western Baltic herring (Clupea harengus L.). Acta Ichthyologica et Piscatoria 4: 3-21.

Hastie T.J., Pregibon D. 1992. Generalized linear models. Pp. 195 - 248. In: Chambers J.M., Hastie T.J. (eds.) Statistical models in S. Chapman and Hall/CRC Press, Boca Raton FL.

Horbowy J., Podolska M. 2001. Modelling infection of Baltic herring (Clupea harengus membras) by larval Anisakis simplex. ICES Journal of Marine Science 58: 321-330.

Johansen A.C. 1919. On the large spring spawning sea herring (Clupea harengus, L.) in the North-West European waters. Meddelelser fra Kommisionen for Havundersøgelser 5.

Jönsson N., Biester E. 1979. Results of tagging experiments on the Rügen spring herring 1977/78. ICES Document CM/J: 29.

Kabata Z. 1970. Diseases of Fishes, Book 1: Crustacea as enemies of fishes. TFH Publications, Jersey City, NJ.

Khalil L.F. 1969. Larval nematodes in herring (Clupea harengus) from British coastal waters and adjacent territories. Journal of the Marine Biological Association of the United Kingdom 49: 641-659.

Klimpel S., Palm H.W., Ruckert S., Piatkowski U. 2004. The life cycle of Anisakis simplex in the Norwegian Deep (northern North Sea). Parasitology Research 94: 1-9.

Last J.M. 1989. The food of herring, Clupea harengus, in the North-Sea, 1983-1986. Journal of Fish Biology 34: 489-501.

Lester R.J.G. 1990. Reappraisal of the use of parasites for fish stock identification. Australian Journal of Marine and Freshwater Research 41: 855-864.

MacKenzie K. 2002. Parasites as biological tags in population studies of marine organisms: an update. Parasitology 124: 153-163.

MacKenzie K., Abaunza P. 1998. Parasites as biological tags for stock discrimination of marine fish: a guide to procedures and methods. Fisheries Research 38: 45-56.
Mariani S., Hutchinson W.F., Hatfield E.M.C., Ruzzante D.E., Simmonds E.J., Dahlgren T.G., Andre C., Brigham J., Torstensen E., Carvalho G.R. 2005. North Sea herring population structure as revealed by microsatellite analysis. Marine Ecology Progress Series 303: 245-257.

Mosegaard H., Madsen K.P. 1996. Discrimination of mixed herring stocks in the North Sea using vertebral counts and otolith microstructure. ICES Document CM/ H:17.

Podolska M., Horbowy J. 2003. Infection of Baltic herring (Clupea harengus membras) with Anisakis simplex larvae, 1992-1999: a statistical analysis using generalized linear models. ICES Journal of Marine Science 60: 85-93.

Ruzzante D.E., Mariani S., Bekkevold D., André C., Mosegaard H., Clausen L.A.W., Dahlgren T.G., Hutchinson W.F., Hatfield E.M.C., Torstensen E., Brigham J., Simmonds E.J., Laikre L., Larsson L.C., Stet R.J.M., Ryman N., Carvalho G.R. 2006. Biocomplexity in a highly migratory pelagic marine fish, Atlantic herring. Proceedings of the Royal Society B-Biological Sciences 273: 1459-1464.

Sluiters J.F. 1974. Anisakis sp. larvae in the stomachs of herring (Clupea harengus L.). Zeitschrift für Parasitenkunde 44: 279-288.

Smith J.W. 1984. Anisakis simplex (Rudolphi, 1809, det. Krabbe, 1978): length distribution and viability of L3 of known minimum age from herring Clupea harengus L. Journal of Helminthology 58: 337-340.

Smith J.W., Wootten R. 1978. Anisakis and anisakiasis. Advances in Parasitology 16: 93-163.

Tarling G.A., Matthews J.B.L., Saborowski R., Buchholz F. 1998. Vertical migratory behaviour of the euphausiid, Meganyctiphanes norvegica, and its dispersion in the Kattegat Channel. Hydrobiologia 375/376: 331-341.

Ulmestrand L., Hagström O. 1992. Abundance and distribution of euphausiids (krill) in Skagerrak and Kattegat in February 1984-1992. ICES Document CM/ L: 16.

van Banning P., Becker H.B. 1978. Long-term survey data (1965-1972) on the occurrence of Anisakis larvae (Nematoda: Ascaridida) in herring, Clupea harengus L., from the North Sea. Journal of Fish Biology 12: 25-33.

Received: 9 August 2007

Accepted: 18 October 2007

Published electronically: 30 November 2007 